\title{
Influence of Salicylic Acid on Growth and Bulb Yield of Onion (Allium cepa L.)
}

\author{
Shilpa R. Koppad ${ }^{1 *}$, S.B. Babaleshwar ${ }^{1}$, P.R. Dharmatti ${ }^{2}$ and K.K. Math ${ }^{2}$ \\ ${ }^{1}$ SRF, AINRP on Onion and Garlic, Department Horticulture, UAS, Dharwad, Karnataka, India \\ ${ }^{2}$ AINRP on Onion and Garlic, Department Horticulture, UAS, Dharwad, Karnataka, India \\ *Corresponding author
}

\section{A B S T R A C T}

\begin{tabular}{|l|}
\hline Ke y w o r d s \\
$\begin{array}{l}\text { Onion, Salicylic } \\
\text { acid, Foliar } \\
\text { application. }\end{array}$ \\
\hline Article Info \\
\hline $\begin{array}{l}\text { Accepted: } \\
\text { 21 July 2017 } \\
\text { Available Online: } \\
\text { 10 September } 2017\end{array}$ \\
\hline
\end{tabular}

Keywords

\section{Introduction}

Onion (Allium cepa L.) is one of the commercial vegetable and spice crops of India and belongs to the family Alliaceae. The area and production of onion in India is about 1181 '000 hectares and 18924'000 tonnes of bulb, respectively, with an average yield of 16 $\mathrm{t} \mathrm{ha}^{-1}$ (NHB, 2015). In India, about 60 percent of onion is predominantly cultivated during winter followed by $20 \%$ each in kharif and late kharif seasons. The reason for lower productivity of onion in India is primarily due to cultivation of low yield potential varieties having susceptibility to both biotic and abiotic stresses. Onion is an important commercial crop exposing to wide array of damaging agents including biotic (pathogens and insects) and abiotic (drought, salinity, heat, cold and poor soil fertility) environmental aggressions. To cope up with these continuous challenges under field conditions, plants have evolved broad and efficient mechanism to obtain an adequate defense and one more such mechanism against pathogen attack is the synthesis of vast array of low molecular weight components with disparate functions in plant pathogen interactions (Dixon, 2001). SA is recently included in the class of phytohormones for proper plant growth and development and induction of tolerance to both biotic as well as abiotic stresses. In general, SA is an important defensive signal in plants essential for elicitor triggered immunity and establishment of systemic acquired resistance (SAR) (Carr et 
al., 2010.) Thus, SA is an endogenous growth regulator of several physiological processes in crop plants such as stomata closure, ion uptake, inhibition of ethylene biosynthesis and transpiration (Khan et al., 2003 and Shakinova et al., 2003). In addition to its role towards biotic stress, SA is also believed to play a key role plant responses to many stresses as ozone (Kochroo et al., 2000), heat (Dat et.al, 1998), chilling (Janda et al., 1999 and Metway et al., 2003), drought stress (Senaranta et al., 2000; Singh and Usha, 2003) etc.

These studies clearly suggests the involvement of SA in realization of different anti stress functions in crop plants, but not much information was available on the efficacy of SA in one of the most important export oriented commercial vegetable crop of India, onion. Keeping this in view, a field experiment was conducted under All India Network Project on Onion and Garlic operating at College of Agriculture, Dharwad, Karnataka, India during rabi 2014-15 to study the effect of SA on growth and yield of onion.

\section{Materials and Methods}

Soil of the experimental site was clay in texture with neutral $\mathrm{pH}$ (6.95) low in soluble salts content (EC $1.82 \mathrm{dsm}^{-1}$ ), low in available nitrogen (228.5 kg ha-1), medium in available phosphorous (21.10 $\left.\mathrm{kg} \mathrm{P}_{2} \mathrm{O}_{5} \mathrm{ha}^{-1}\right)$, high in available potassium $\left(620 \mathrm{~kg} \mathrm{ha}^{-1}\right)$, sufficient in available sulphur ( $\left.30.00 \mathrm{~kg} \mathrm{ha}^{-1}\right)$ The field trail was laid out by Randomized Block Design with six treatments replicated four times. The six treatment schedule consisted of foliar application of SA (SA) at $250 \mathrm{mg} \mathrm{l}^{-1}$ at 30 days of sowing (DAS) and second spraying at 30 days after transplanting (DAT) $\left(\mathrm{T}_{1}\right)$, foliar application of SA at 30 DAT and second spraying at 45 DAT $\left(\mathrm{T}_{2}\right)$, foliar application of SA at 30 DAT and second spraying at $60 \mathrm{DAT}\left(\mathrm{T}_{3}\right)$, Foliar application of
SA at 30 days after sowing and second spraying at 30 days after transplanting and third spray at 45 days after transplanting $\left(\mathrm{T}_{4}\right)$, Foliar application of SA at 30 DAT and second spray at 60 DAT $\left(\mathrm{T}_{5}\right)$, along with untreated control i.e., without SA water spray only $\left(\mathrm{T}_{6}\right)$. The onion variety Bhima Shakti seedlings were raised in nursery bed. The seedlings were sprayed with SA @ $250 \mathrm{mg} \mathrm{l}^{-1}$ 30 DAT except the control treatment. Forty five 45 days old seedlings of 10-15 cm height were transplanted in the main field at a spacing of $15 \mathrm{~cm}$ X $10 \mathrm{~cm}$. the crop was raised by following the recommended package of practice and the treatments were imposed as per the schedule. The data recorded on various parameters were subjected to statistical analysis as per the procedure suggested by Panse and Shukatme (1978).

\section{Results and Discussion}

\section{Growth parameters of onion}

The data given in table 1 indicated that, different treatments did not significantly influence plant height in onion. However foliar application of SA (SA) at $250 \mathrm{mg} \mathrm{l}^{-1}$ at 30 days after sowing followed by 30 and 45 days after sowing $\left(\mathrm{T}_{4}\right)$ recorded higher plant height closely followed by $T_{3}$ and $T_{5}$. Similarly $\mathrm{T}_{4}$ recorded the highest number of leaves per plant and was significantly superior to control but statistically similar to other treatments. Numerically the highest collar thickness was recorded in $\mathrm{T}_{4}(15.56 \mathrm{~mm})$ and was followed by $\mathrm{T}_{3}(14.72 \mathrm{~mm})$ control with no SA treatment recorded the lowest value $(13.72 \mathrm{~mm})$. These results indicated that foliar application of SA to onion improved crop growth and the extent of improvement was more in the treatment with more number of foliar sprays. The beneficial effect of SA on crop growth might be due to its involvement in several physiological processes in plants such as stomatal opening and closing, 
nutrients uptake and inhibition of biosynthesis and transpiration. (Khan et al., 2003 and Shakirova et al., 2003) SA had also prolific effects on both morphology and physiology of plants. (Piperpoint, 1996 and Poncheva et al., 1996) Exogenous application of SA increases photosynthetic activity which enhances the plant height and number of leaves per plant (Gharib, 2006) Similar reports on beneficial effects of SA on vegetative in form of plant height, number of leaves per plant, chlorophyll content of leaves have also been reported in several crops, such as E1- Tayeb (2005) in chilli, Amin et al., 2007 in onion, Gawade and Sirohi (2011) in brinjal and Khandaner et al., (2011) in red amaranthus etc.

Yield and yield attributes and bulb yield of onion

The results on yield attributing parameters of onion variety Bhima Shakti revealed that there was a significant variation in onion bulb diameter (polar and equatorial) and average bulb weight, doubles and bolters percentage due to spaying of SA at different times (Table 2). Significantly maximum polar diameter (PD) of $62.72 \mathrm{~mm}$ was recorded in $\mathrm{T}_{4}$ followed by $\mathrm{T}_{5}(61.41 \mathrm{~mm})$. Similarly, maximum equatorial diameter (ED) was also recorded in $\mathrm{T}_{4}(51.40 \mathrm{~mm})$ followed by $\mathrm{T}_{3}$ $(54.05 \mathrm{~mm})$ as compared to control (47.75 $\mathrm{mm})$.

The average bulb weight was higher in $\mathrm{T}_{4}$ $(69.32 \mathrm{gm})$ followed by $\mathrm{T}_{5}(68.17 \mathrm{gm}) \mathrm{T}_{3}$ $(68.16 \mathrm{gm})$ and $\mathrm{T}_{4}$ maintained statistical purity with all the treatments but significantly superior to control which recorded the lowest value $(65.07 \mathrm{gm})$. Further $\mathrm{T}_{4}$ also recorded lower values for doubles and bolters percentage (2.50) and (3.06) respectively but control with no SA treatment recorded the highest values (6.25) and (4.71) respectively. The better efficacy of SA increasing the effective photosynthetic area interms of plant height, number of leaves per plant and chlorophyll content significantly enhance the assimilation of photosynthates in the bulb. Results of higher values of polar and equatorial diameter in onion bulbs also reported by Amin et al., (2007), Pradhan et al., (2016) in onion and Bideshiki and Arvin (2010) in garlic. The increased bulb weight in the present study due to foliar application of SA to onion might be due to the better utilization of photosynthesis and increased allocation of photosynthates towards the economic parts i.e., bulbs in onion. Several studies indicated that SA may have a dramatic effect on sugar metabolism in plants. Sugars, the form of simple carbohydrates are well known for their role in plant metabolism in all living cells (Hirabayashi, 1996). In general, both glucose and fructose are the primary sucrose of carbon and energy for plant cells. In oxygenic photosynthesis and is a transport molecule in plant growth development and storage (Couee et al., 2006). Similar report on better efficacy of SA over control was also reported in onion by Amin et al., (2007), Pradhan et al., (2016), garlic by Bideshki and Arvin (2010) and green pea by Hak et al., (2012) in green pea.

The results presented on total bulb yield and marketable bulb yield of onion variety Bhima Shakti revealed numerical variations among different treatments due to exogenous application of SA (Table 2). The results indicated that numerical higher total bulb yield of $41.75 \mathrm{t} \mathrm{ha}^{-1}$ in $\mathrm{T}_{4}$ than rest of the treatments followed by $\mathrm{T}_{3}(40.35 \mathrm{t} / \mathrm{ha})$ and $\mathrm{T} 5$ (37.68 t/ha).

Numerically higher marketable yield was also observed higher in the $\mathrm{T}_{4}(39.22 \mathrm{t} / \mathrm{ha})$ followed by $\mathrm{T}_{3}(38.90 \mathrm{t} / \mathrm{ha})$ and $\mathrm{T}_{5}$ (34.99 t/ha). Similar report of higher bulb yield in onion with application of SA than the control was also reported by Amin et al., (2007). 
Table.1 Effect of SA on growth parameters of onion

\begin{tabular}{|c|c|c|c|}
\hline Treatment & PH $(\mathbf{c m})$ & NOL & CTh $(\mathbf{m m})$ \\
\hline T1 & 66.88 & 7.45 & 13.92 \\
\hline T2 & 67.98 & 7.65 & 14.21 \\
\hline T3 & 68.37 & 7.80 & 14.72 \\
\hline T4 & 68.98 & 8.35 & 15.56 \\
\hline T5 & 68.24 & 7.95 & 13.97 \\
\hline T6 & 64.90 & 7.20 & 13.72 \\
\hline SEm & 3.93 & 0.30 & 0.72 \\
\hline CD @ 5\% & 11.85 & 0.92 & 2.18 \\
\hline CV \% & 11.63 & 7.96 & 10.18 \\
\hline
\end{tabular}

Table.2 Effect of SA on yield and yield parameters of onion

\begin{tabular}{|c|c|c|c|c|c|c|c|}
\hline Treatment & PD (mm) & ED (mm) & Avg. wt of bulb & TBY (t/ha) & MY (t/ha) & Double (\%) & Bolters (\%) \\
\hline T1 & 58.27 & 47.75 & 67.66 & 35.78 & 33.64 & 5.25 & 3.33 \\
\hline T2 & 60.23 & 49.29 & 67.32 & 35.93 & 32.91 & 5.19 & 3.33 \\
\hline T3 & 60.65 & 50.40 & 68.16 & 40.35 & 38.90 & 5.06 & 3.11 \\
\hline T4 & 62.72 & 54.04 & 69.32 & 41.75 & 39.22 & 2.50 & 3.06 \\
\hline T5 & 61.41 & 51.40 & 68.17 & 37.68 & 34.99 & 3.45 & 3.11 \\
\hline T6 & 56.01 & 47.75 & 65.07 & 34.10 & 31.81 & 6.25 & 4.71 \\
\hline SEm & 0.69 & 1.08 & 1.26 & 3.25 & 3.60 & 0.89 & 0.67 \\
\hline CD @ 5\% & 2.08 & 3.26 & 3.79 & 9.81 & 10.85 & 2.68 & 0.02 \\
\hline CV \% & 2.30 & 4.35 & 3.72 & 17.39 & 20.53 & 38.60 & 9.49 \\
\hline
\end{tabular}

Table.3 Effect of SA on cost of cultivation of Onion

\begin{tabular}{|c|c|c|c|c|c|}
\hline Treatment & Cost of cultivation (Rs/ha) & Yield (t/ha) & Gross income (Rs/ha) & Net returns (Rs/ha) & B:C ratio \\
\hline $\mathrm{T}_{1}$ & $82,270.5$ & 35.78 & $10,73,400$ & $9,91,129.5$ & 12.04 \\
\hline $\mathrm{T}_{2}$ & $82,270.5$ & 35.93 & $10,77,900$ & $9,95,629.5$ & 12.10 \\
\hline $\mathrm{T}_{3}$ & $82,270.5$ & 40.35 & $12,10,500$ & $11,28,229.5$ & 13.71 \\
\hline $\mathrm{T}_{4}$ & $84,053.5$ & 41.75 & $12,52,500$ & $11,68,446.5$ & 13.90 \\
\hline $\mathrm{T}_{5}$ & $84,053.5$ & 37.68 & $11,30,400$ & $10,46,346.5$ & 12.44 \\
\hline $\mathrm{T}_{6}$ & $78,704.5$ & 34.10 & $10,23,000$ & $9,44,295.5$ & 11.99 \\
\hline
\end{tabular}

The higher marketable yield might be due to enhanced assimilation of nutrient uptake, nutrient reduction and photosynthesis improved flow assimilates and increased cell integrity which in term reflected on the increased bulb yield of the onion plants. Better efficacy of SA in garlic was also reported by Bideshki and Arvin (2010), which might be due to accumulation of more chlorophyll content in SA treated plants, responsible for the improved fresh and dry matter accumulation there by final bulb yield.

\section{Economics}

The findings obtained from table 3, indicated the marked variations among treatments in respect of cost of cultivation. Onion also 
reiterates the beneficial effect of foliar application of SA to onion. $\mathrm{T}_{4}$ recorded the highest gross (Rs. 12,52,500) and net returns (Rs. 11,68,446.5) with higher $\mathrm{B}: \mathrm{C}$ ratio (13.90) and was followed by $\mathrm{T}_{3}$ and control recorded the lowest returns. The higher net returns due to foliar application of SA to onion might be attributed to higher total and marketable yields.

From this study it could be concluded that foliar spray of SA (SA) is essential for onion crop. Foliar spray of SA at 30 days after sowing during nursery seedling stage, subsequently second spray at 30 days after transplanting and third spray at 45 or 60 days after transplanting during crop growth stage not only increased the vegetative growth but also the bulb yield of onion variety Bhima Shakti.

\section{References}

Amin, A.A., Rashad, M., EL-Sh, EL-Abagy, H.M.H., 2007. Physiological effect of indole-3-butyric acid and salicylic acid on growth, yield and chemical constituents of onion plants. Journal of Applied Science Research 3(11), 1554-1563.

Bideshki, A., Arvin, M.J., 2010. Effect of salicylic acid (SA) and drought stress on growth bulb yield and allicin content of garlic in field. Plant Ecophysiology 2, 73-79.

Carr, J.P., Lewsey, M.G., Palukaitis, P., 2010. Signaling in induced resistance. Advances in Virus. Research 76, 57121.

Couee, I., Sulmon, C., Gouesbet, G., Amrani, A.E., 2006. Involvement of soluble sugars in reactive oxygen species balance and responses to oxidative stress in plants. Journal of Experimental Botany 57(3), 449-459.

Dat, J.F., Foyer, C.H., Scote, I.M., 1998.
Changes in Salicylic acid and antioxidants during induced thermo tolerance in mustard seedlings. Plant Physiology 118, 1455-1466.

Dixon, R.A., 2001. Natural product and plant disease resistance. Nature 411, 843-847.

El-Tayeb, M.A., 2005. Response of barley grains to the interactive effect of salinity and salicylic acid. Plant Growth Regulator 45, 215-224.

Gawade, B., Sirohi, A., 2011. Induction of Resistance in Eggplant (Solanum melongena) by Salicylic Acid against Root-Knot Nematode, Meloidogyne incognita. Indian Journal of Nematology 41(2), 201-205.

Gharib, F.A., 2006. Effect of salicylic acid on the growth, metabolic activities and oil content of basil and marjoram. International Journal of Agricultural Biology 4, 485-492.

Hak, E.L., Gunes, A., Inal, A., Alpaslan, M., Eraslan, F., Guneri, B.E., Cicek, N., 2012. Salicylic acid induced changes on some physiological parameters symptomatic for oxidative stress and mineral nutrition in green pea (Pisum sativum) grown under salinity. Journal of Plant Physiology 164, 728-736.

Janda, T., Szalai, G., Tari, I., Paldi, E., 1999. Hydroponic treatment with salicylic acid decreases the effects of chilling injury in maize (Zea mays L.) plants. Planta 208, 175-180.

Kachroo, P., Yoshioka, K., Shah, J., Dooner, H.K., Klessig, D.F., 2000. Resistance to turnip crinkle virus in Arabidopsisis regulated by two host genes and is salicylic acid dependent but NPR1, ethylene, and jasmonate independent. Plant Cell 12, 677-690.

Khan, W., Prithiviraj, B., Smith, D.L., 2003. Photosynthetic responses of corn and soybean to foliar application of salicylates. Journal of Plant Physiology 
160, 485-492.

Khandaker, L., Masum, A.S.M.G., Shinya, O.B.A., 2011. Foliar application of salicylic acid improved the growth, yield and leaf's bioactive compounds in red amaranthus (Amaranthus tricolor). Vegetable Crop Research Bulletin 74, 77-86.

Metwally, A., Finkemeirer, I., Georgi, M., Dietz, K.J., 2003. Salictlic acid alleviates the cadmium toxicity in barley seedlings. Plant Physiology 132, 272-282.

Pierpoint, W.S., 1994. Salicylic acid and its derivatives in plants: medicines, metabolites and messenger molecules. Botanical Research 20, 163-235.

Poncheva, T.V., Popova, L.P., Uzunova, A.N., 1996. Effect of salicylic acid on growth and photosynthesis in barley plants. Journal of Plant Physiology 149, 57-63.
Pradhan, M., Tripathy P., Mandal P., Sahoo B. B., Pradhan R., Mishra S. P., Mishra H. N., International Journal of Bio resource and stress management. 17, 960-963

Seneratna, T., Touchell, D., Bunn, E., Dixon, K., 2000. Aceta salicylic acid (Asprin) and salicylic acid induce multiple stress tolerance in bean and tomato plants. Plant Growth Regulator 30, 157-161.

Shakirova, M.F., Sakhabutdinova, A.R., Bezrukova, M.V., Fathutdinova, R.A., Fathutdinova, D.R., 2003. Change in the hormonal status of wheat seedling induced by salicylic acid and salinity. Plant Science 164(3), 317-322.

Singh, B., Usha, K., 2003. Salicylic acid induced physiological and biochemical changes in wheat seedlings under water stress. Plant Growth Regulator 39, 137-141.

\section{How to cite this article:}

Shilpa R. Koppad, S.B. Babaleshwar, P.R. Dharmatti and Math, K.K. 2017. Influence of Salicylic Acid on Growth and Bulb Yield of Onion (Allium cepa L.). Int.J.Curr.Microbiol.App.Sci. 6(9): 1732-1737. doi: https://doi.org/10.20546/ijcmas.2017.609.214 